\title{
Going Public, Selling Stock, AND Buying LIQUIDITY
}

\author{
RICHARD A. BOOTH*
}

\begin{abstract}
One would think that the existing stockholders of companies going public would be outraged at the failure of their investment bankers to do a better job at setting prices for IPOs, and indeed, there was a spate of litigation following the dotcom bust. However for the most part, those who complained were investors who had been cajoled into buying shares in the aftermarket.
\end{abstract}

\section{INTRODUCTION}

It is a well-known anomaly of corporate finance that initial public offerings ("IPOs") tend to be underpriced.' That is, it appears that shares tend to be offered at a price that is below what the market would bear. In a few cases toward the end of the dotcom frenzy, IPO shares rose by as much as 500 percent during the first day of trading. ${ }^{2}$ To be sure, much of that price pop is often dissipated in the days and weeks that follow. Indeed, investors who buy newly offered shares in the aftermarket (rather than receiving an allocation from their broker at the offering price) often end up with a loss. ${ }^{3}$ Nevertheless, on average and over the long haul, IPOs tend to rise from their offering price by more than other shares of similar risk by about eighteen percent. ${ }^{4}$

\footnotetext{
* Martin G. McGuinn Professor of Business Law, Villanova University School of Law.

${ }^{1}$ See Anita Indira Anand, Is the Dutch Auction IPO a Good Idea?, 11 STAN. J.L. Bus. \& FIN. 233 (2006); Royce de Rohan Barondes et al., IPO Spreads: You Get What You Pay For (2000), available at http://ssrn.com/abstract=233146; Sean J. Griffith, Spinning and Underpricing: A Legal and Economic Analysis of the Preferential Allocation of Shares in Initial Public Offerings, 69 BROOK. L. REV. 583 (2004); Christine Hurt, Moral Hazard and the Initial Public Offering, 26 CARDOZO L. REv. 711 (2004); Christine Hurt, What Google Can't Tell Us About Internet Auctions (And What It Can), 37 U. TOL. L. Rev. 403 (2006); Peter B. Oh, The Dutch Auction Myth, 42 WAKE FOREST L. REV. 853, 861 (2007); Jonathan A. Shayne \& Larry D. Soderquist, Inefficiency in the Market for Initial Public Offerings, 448 VAND. L. REV. 965 (1995).

${ }^{2}$ The record apparently belongs to VA Linux Systems whose IPO rose $697.50 \%$ on December 9, 1999. See Therese H. Maynard, Spinning in a Hot IPO-Breach of Fiduciary Duty or Business as Usual?, 43 WM. \& MARY L. REV. 2023 (2002).

${ }^{3}$ Shayne \& Soderquist, supra note 1, at 970 (finding that IPOs bought at the first day closing price returned less than seasoned stocks); Terzah Ewing, Burnt Offerings? Street Debuts Are Fizzling After Pop, WAll ST. J., Apr. 26, 2000, at C1.

${ }^{4} \mathrm{Oh}$, supra note 1 , at 3 .
} 
One would think that the existing stockholders of companies going public would be outraged at the failure of their investment bankers to do a better job at setting prices for IPOs, and indeed, there was a spate of litigation following the dotcom bust. However for the most part, those who complained were investors who had been cajoled into buying shares in the aftermarket. $^{5}$ It appears that issuers and existing stockholders are quite happy when the stock soars following an IPO despite the fact that a big pop in price would suggest that the company could have sold the shares at a higher price and thus been worth that much more. ${ }^{6}$ In effect, underpricing raises the cost of going public and makes equity capital that much more expensive than it would otherwise be. ${ }^{7}$

\section{THE UNDERPRICING PROBLEM}

What explains the persistence of underpricing in the market for initial public offerings? There are several unsavory explanations.

First, underpricing reduces risk for underwriters. In a traditional fixed-price, firm-commitment offering, the underwriter agrees to buy the shares being offered at a discount of typically seven percent off the offering price, and then undertakes to resell them to investors at the price specified in the offering. In other words, the issuer gets the money up front (less the underwriting discount). If the underwriter cannot resell the shares, the underwriter loses. ${ }^{8}$ Therefore, one explanation for underpricing is that

\footnotetext{
${ }^{5}$ See e.g. Credit Suisse Securities (USA) LLC v. Billing, 127 S. Ct. 2383, 2389 (2007);

In re Initial Public Offering Securities Litigation, 471 F.3d 24 (2d Cir. 2006).

${ }^{6}$ See Hurt, supra note 1, at 6; Oh, supra note 1, at 627-28; Robert McGough \& Randall Smith, IPO Issuers Don't Mind Money Left on the Table, WALL ST. J., Nov. 3, 1999, at $\mathrm{C} 1$; Timothy $\mathbf{J}$.

Mullaney, Is the Street Lowballing IPOs?, Bus. WK., Apr. 3, 2000, at 112. The litigation following the dotcom bust was prompted primarily by share allocation practices and has been prosecuted in many cases by creditors who succeeded to ownership as a result of issuer bankruptcy.

${ }^{7}$ See generally NYSE / NASD IPO ADVISORY COMMITTEE REPORT AND

RECOMMENDATIONS (May 2003),

http:/www.finra.org/web/groups/rules regs/documents/rules regs/p010373.pdf.

${ }^{8}$ See Sean J. Griffith, The Puzzling Persistence of the Fixed Price Offering: Implicit

Price Discrimination in IPOs (2005), available at http://ssrn.com/abstract=797865.

There are other possible models. In a best efforts underwriting, the underwriter attempts to sell the offered securities but does not buy them up front. Many such offerings are made on an all or nothing basis. That is, the securities are ultimately sold only if the underwriter is able to sell the entire offering. In the UK, the traditional arrangement is for the underwriter to guarantee the offering by agreeing to buy any unsold shares. One might call such an arrangement a true underwriting. See Coffee, et al., SECURITIES REGULATION $67\left(10^{\text {th }}\right.$ ed. 2007) for a description of various possible underwriting arrangements.
} 
underwriters set a low price in order to assure that the offering will sell out quickly - "go out the window" in the argot of Wall Street."

Second, underpricing reduces litigation risk for underwriters. ${ }^{10}$ Under the Securities Act of 1933 ("1933 Act"), the underwriter is liable for damages if there is a misrepresentation or omission of any material fact in the registration statement or prospectus. ${ }^{11}$ But the underwriter is liable only for the difference between the offering price and the value of the shares after corrective disclosure or rescission, and practically speaking, only for one year following the date of the offering. ${ }^{12}$ There are relatively few defenses to a claim under the $1933 \mathrm{Act}$, so investors are likely to sue whenever the market price falls below the offering price during the first year following the offering. After all, one can usually find some sort of misstatement or omission somewhere in a document the size of a registration statement or prospectus. ${ }^{13}$ The problem is that stocks rise and fall for all sorts of reasons. Indeed, almost all stocks tend to rise and fall with the market, and the market can easily fall by as much as ten or twenty percent in the space of a year. Moreover, IPO stocks tend to be somewhat riskier than the market as whole and therefore tend to fall more than the market as a whole when the market as a whole declines. ${ }^{14}$ Thus, underpricing may be intended to hedge against the possibility of litigation under the 1933 Act as a result of extraneous market fluctuations. If so, the problem would seem to be more with the 1933 Act than it is with underwriters. ${ }^{15}$

\footnotetext{
${ }^{9}$ See Oh, supra note 1 , at 625 .

${ }^{10}$ See id. at 628-29.

${ }^{11}$ Securities Act of 1933 , 15 U.S.C. $\$ 77 \mathbf{k}$ (2006)(providing for damages remedy in connection with misrepresentation or omission in registration statement); $\S 771$ (providing for rescission in connection with misrepresentation or omission in prospectus). The issuer is strictly liable under $\S 77 \mathrm{k}$, but the underwriter and others may assert a due diligence defense. A similar defense is available under $\S 771$, which applies to sellers.

${ }^{12} 15$ U.S.C. $\$ 77 \mathrm{~m}$ (providing for one year statute of limitations with three year repose); $\S 77 \mathrm{k}$ (requiring proof of reliance after issuer has reported earnings for 12 month period following effective date of registration statement).

${ }^{13}$ See, e.g., Wielgos v. Commonwealth Edison Co., 892 F.2d 509 (7th Cir.

1989) (dismissing 1933 Act action against issuer electric utility claiming that issuer should have warned about the possibility of adverse regulatory action).

${ }^{14}$ See Richard A. Booth, Windfall Awards Under PSLRA, 59 BUS. LAw. 1043 (2004).

${ }^{15}$ That is, underpricing provides protection from the risk of liability because the market price must fall below the offering price for the underwriter to be exposed to liability.

See Stanford Clearinghouse for data about the minimum/average price decline that typically triggers a 1933 Act action. Moreover, given that IPOs tend to be concentrated in up markets, the chance of a downturn would seem to be somewhat enhanced. To be sure, one might argue that underpricing tends to undermine the fundamental goal of federal securities law at the expense of issuers. On the other hand, it is likely in the case of any serious fraud that share price will fall well below offering price even if the offering is underpriced. Therefore, it seems quite possible that the market has
} 
Third, underwriters may use underpricing as currency for many other purposes. It can be used to reward good customers or to attract new business, or it can be used as part of a package deal in which investors agree to buy other securities or services at prices that are less attractive. ${ }^{16}$ Indeed, such practices were at the core of much of the IPO litigation (both civil and criminal) that followed the dotcom bust. ${ }^{17}$

It is important to note that the underwriter cannot sell shares for more (or less) than the specified offering price in a fixed price offering. Because the offering price is stated in the registration statement and the prospectus, it is illegal to sell shares that are part of the offering at any other price. Obviously, if it were possible for the underwriter to follow the market up and sell shares at higher prices as the market price rises, it would be tempting to do so. So why is it that there are no at-the-market IPOs? ${ }^{18}$ The underwriter could double its fee if the subject stock doubled in price during the first day. One answer is that under the 1933 Act, an underwriter would be at risk to the extent that the market price declines from the price at which shares are sold as part of the offering, so it is not clear that underwriters would want to do an at-the-market IPO even if they could. Given the liability rules under the 1933 Act, it is much safer to stick with a fixed price offering and use the gain as currency for other purposes. Indeed, if the gain to underwriters from other uses of underpricing exceeds the additional fees that could be earned without underpricing-and they

effectively struck a workable balance between investor protection and investor opportunism.

${ }^{16}$ See Oh, supra note 1, at 630-32. See also Stephen J. Choi \& A.C. Pritchard, Should Issuers Be on the Hook for Laddering? An Empirical Analysis of the IPO Market Manipulation Litigation, 73 U. CIN. L. REv. 179 (2004); Peter H. Huang, New Perspectives and Legal Implications: Trust, Guilt, and Securities Regulation, 151 U.PA. L. REV. 1059 (2003); Ely R. Levy, The Law and Economics of IPO Favoritism and Regulatory Spin, 33 Sw. U. L. REV. 185 (2004); Peter B. Oh, Gatekeeping, 29 J. CORP. L. 735 (2004); Lucas C. Townsend, Comment, Can Wall Street's "Global Resolution" Prevent Spinning? A Critical Evaluation of Current Alternatives, 34 SETON HALL L. REV. 1121 (2004). Some commentators have also suggested that IPO pricing and success may be related to the prestige of the lawyers involved. See Royce de Rohan Barondes et al., Law Firm Prestige and Performance in IPOs: Underwriters' Counsel as Gatekeeper or Turnstile, Contracting and Organizations Research Institute, Working Paper No. 03-08, (2004); Royce de Rohan Barondes \& Gary C.Sanger, Lawyer Experience And IPO Pricing (2000), available at http://ssrn.com/abstract=227729. ${ }^{17}$ See e.g. Credit Suisse Securities (USA) LLC v. Billing, 127 S. Ct. 2383, 2389 (2007); In re Initial Public Offering Securities Litigation, 471 F.3d 24, 27 (2d Cir. 2006).

${ }^{18}$ It is not clear that the SEC would approve an at-the-market IPO. Although the 1933 Act is not supposed to dictate the terms of an offering, it is not clear that it is possible to file a registration statement for an IPO without specifying an offering price. Although there are rules and forms that specifically contemplate at-the-market offerings by companies that are already public, none is available for use in connection with an IPO. See, e.g., SEC Form S-3; see also Hurt, supra note 1, at 8. 
easily could - investment bankers would have no interest in changing the system. $^{19}$

One final explanation (of sorts) for underpricing is that those with standing to complain otherwise gain from the practice. Although the issuer could have raised more money, the stockholders see the value of their own stock skyrocket. On the other hand, the company (and the existing stockholders' stock) would be worth still more if the company sold its stock at a higher price. ${ }^{20}$ But the thinking (or double thinking) may be that if the issuer tries to squeeze too much out of the offering, investors will not be as eager to bid up the price.

Notwithstanding the foregoing theories that blame underpricing on underwriters, there must be more to the story. Underwriters have every incentive to maximize offering price. With the standard flat rate discount of seven percent, the underwriter stands to make more money at a higher offering price. $^{21}$ Moreover, underwriters should compete with one another

\footnotetext{
${ }^{19}$ See Oh, supra note 1 , at 631.

${ }^{20}$ See Hurt, supra note 1, at 6; Oh, supra note 1, at 867-68; Raymond Hennessey, StartUps Still Fail to Benefit Fully as IPO Prices Soar, WALL ST. J., Feb. 28, 2000, at C21. One might think that the corporation and the selling stockholders (if any) would have a claim against the underwriters who serve as their agents, but such claims are typically waived as a condition of the underwriting agreement (despite the fact that the SEC regards such waivers as contrary to public policy). Moreover, given that one has no standing to sue for an injury to the corporation unless one is a stockholder at the time of the wrong, there is usually no one left who can sue the underwriter.

${ }^{21}$ Competition works slowly in the underwriting market. See United States v. Morgan, 118 F. Supp. 621 (S.D.N.Y. 1953). Traditionally, issuers seldom switch underwriters. But see Michael Siconolfi, More Firms Switch Underwriters, WALL
} ST. J., Dec. 19, 1996, at C1; Mullaney, supra note 6, at 112 (reporting that many firms switch underwriters for follow-on offerings possibly because of underpricing of IPO); Randall Smith \& Thomas T. Vogel, Jr., Time Warner Muscles Its Underwriters, WALL ST. J., Jan. 28, 1993, at C1 (reporting that Time Warner was able to dictate terms of a series of deals because of competition among underwriters seeking the business). To be sure, underwriters appear to compete vigorously to win client companies in the first place. Indeed, such competition was at the heart of many of the alleged abuses during the dotcom frenzy, and it does appear that some underwriters are better at pricing than others. Oh, supra note 1, at 869-70. Presumably, issuers will seek out the best underwriter they can retain, though it may be that the best underwriters will be choosy about the issuers they take on. One significant problem is that the price for an IPO is never fixed until the night before the offering. By then, the offering has entailed so much work and expense that an issuer would be reluctant to call it off. Moreover, the issuer is in no position to argue with an underwriter who advises that market conditions dictate a lower than anticipated price. After all, the issuer and its controlling stockholders seldom do more than one IPO, whereas the underwriter is a repeat player. Therefore, it is possible that underwriters can engage in bait and switch tactics if they want to do so. But again, an underwriter is a repeat player in the market and knows that word will get around if it engages in opportunistic tactics. 
to sell an issuer's stock at the highest possible price. ${ }^{22}$ Indeed, several firms have sought to develop ways to capture the benefit of underpricing for their issuer clients. ${ }^{23}$ Most notably W. R. Hambrecht \& Co. and Wit Capital Group have used the internet to conduct Dutch Auction offerings. ${ }^{24}$ The results have been mixed at best. ${ }^{25}$ In addition, there are numerous alternatives to underwritten offerings ranging from do-it-yourself sales over the internet to out and out stock giveaways. ${ }^{26}$ Yet none of these alternatives has made much of a dent in the traditional IPO business, where underpricing remains common. ${ }^{27}$

\section{DUTCH AUCTION OFFERINGS}

Leaving aside for the moment the question of why traditional IPOs tend to be underpriced, one possible solution is to conduct IPOs by means of a modified Dutch Auction. ${ }^{28}$ In a Dutch Auction Offering (DAO), the underwriter in effect solicits bids for the offering from potential investors, including the price that the investor is willing to pay and the quantity that the investor is willing to buy. After all the bids are compiled, the issuer (underwriter) sells the stock at the highest price that will result in selling all the shares - the clearing price. Investors who bid higher than the clearing price are allocated the quantity for which they bid at the clearing price even though they bid more. But, there may be more investors who bid exactly the clearing price than there are shares that remain available after filling the orders of those who bid higher. If so, the remaining shares are allocated pro rata to the investors who bid that price. ${ }^{29}$

\footnotetext{
${ }^{22}$ See Oh, supra note 1.

${ }^{23}$ Anthony Perkins, IPOs Go Dutch, and Small Investors Gain, WALL ST. J., Dec. 12, 1999 , at A 18.

${ }^{24}$ Wit Capital later became Soundview Technology Group and was acquired by Schwab.

${ }^{25}$ See generally Hurt, supra note 1; Oh, supra note 1; Randall Smith, So Far, 'EUnderwriting' Gets a Slow Start, WALL ST. J., Aug. 13, 1999, at C1; Terzah Ewing, Too Hot an IPO? Andover.net's 252\% Pop Raises Questions About Underwriter's 'Dutch Auction, WALL ST. J., Dec. 9, 1999, at C1. See also Anand, supra note 1.

${ }^{26}$ See generally Denis T. Rice, Recent Developments in Offering Securities on the Internet, in ANNUAL DEVELOPMENTS IN BUSINESS FINANCING (ABA Section of Business Law, 2000).

${ }^{27}$ See generally Griffith, supra note 8.

${ }^{28}$ See Anand, supra note 1; Hurt, supra note 1; Oh, supra note 1.

${ }^{29}$ In a true Dutch Auction, buyers buy at varying prices until the subject matter sells out. In other words, a true Dutch Auction may involve price discrimination. $C f$. Griffith, supra note 8 (arguing that fixed price offerings involve price discrimination). In addition, DAOs differ from true Dutch Auctions in other ways in order to comply with federal securities law. For example, in a DAO investor offers to purchase do not become binding until the offer is priced because federal securities law prohibits the formation of contracts to buy before a registration
} 
For example, suppose that Sunshine Desserts Corporation wants to sell 1,000,000 shares. Its underwriter receives the following bids leading up to the offering.

$$
\begin{array}{r}
50,000 \text { at } 25 \\
150,000 \text { at } 24 \\
300,000 \text { at } 22 \\
400,000 \text { at } 21 \\
500,000 \text { at } 20
\end{array}
$$

The offering price would be set at 20 but 900,000 shares would go (at 20 ) to investors who were willing to pay more. Only 100,000 would remain for those investors who bid 20 , and they would be allocated only 20 shares for each 100 shares for which they bid. ${ }^{30}$

statement goes effective. See generally Hurt, supra note 1. Modified Dutch Auctions are used in several other settings involving securities, including the sale of Treasury bonds and repurchases of stock. See also Moshe Burnovski, Reverse Price Tender Offers, 56 GEO. WASH. L. REV. 295 (1988). It is noteworthy that US law has an inexplicable but strong egalitarian streak. Not only does the 1933 Act effectively dictate fixed price offerings, the 1934 Act rules relating to tender offers require that the same price be paid to all tendering stockholders, and many states have adopted fair price statutes that require that the same price be paid in a follow up merger as is paid in a front end tender offer. See Richard A. Booth, The Problem with Federal Tender Offer Law, 77 CAL. L. REV. 707 (1989); Richard A. Booth, The Promise of State Takeover Statutes, 86 MICH. L. REV. 1635 (1988). And as a matter of antitrust law, the Robinson-Patman Act generally prohibits price discrimination. 15 U.S.C. $\$ 13(2006)$.

${ }^{30}$ One of the problems with a DAO is that technically bids are not legally enforceable until the price is set and the registration statement becomes final. That might permit bidders to game the system by entering false bids that would be unenforceable if the investor changes his mind. This risk is minimized by underwriters accepting winning bids as of the moment the registration goes effective. Therefore, the danger of placing a false bid is that it might be accepted. On the other hand, the danger in a traditional offering is that the price will be set higher than expected, so a DAO is less risky for investors than is a traditional offering. That in turn may induce investors to bid a bit more (or order a few more shares) than they otherwise would. This suggests yet another reason for underpricing, namely, that it compensates investors for effectively committing to buy shares before they know the price. Chalk and Peavey have suggested a similar theory for underpricing before the advent of DAOs. They argue that book building is essentially a discriminatory auction in which potential investors have no way of knowing the reservation prices of other investors. Once the offering is complete, the shares become the subject of a continuous competitive auction in the aftermarket in which buy and sell orders equilibrate. Investors face less risk because price discovery is more efficient. All are therefore willing to pay a bit more. Hence the price of the subject stock tends to rise. See Andrew J. Chalk \& John W. Peavy III, Understanding the Pricing of Initial Public Offerings, 8 RES. Fin. 203, 206 (1990); Andrew J. Chalk \& John W. Peavy III, IPOs: Why Individuals Don't Get the "Hot" Issues, 9 AAII J. 16 (March 1987). I offer a somewhat similar argument below based on the effects of investor diversification and portfolio investors. These explanations for underpricing may also operate in the context of a DAO, which is also a discriminatory auction. 
The theory is that a DAO should eliminate underpricing by allocating shares to the investors who are willing to pay more. To be sure, most of the investors who are allocated shares would have been willing to pay more, but because their orders were filled, they need not buy shares in the aftermarket. There is no reason for a price pop. In addition, underwriters charge a lower fee (discount) for DAOs. For example, Hambrecht charges just 3\% rather than the standard $7 \%$ that most underwriters charge for a traditional fixed price, firm commitment offering. To some extent, this lower fee may be a temporary special offer designed to attract business, but the lower fee may also reflect lower costs. DAOs use the internet heavily instead of costly road shows and other face-to-face meetings to build a book of investors.

DAOs have succeeded to some extent in eliminating the price pop, but there have been notable exceptions. The question is why have DAOs not made a bigger dent in the traditional underwriting business. Why are there still so few DAOs as compared to traditional fixed price, firm commitment IPOs? One possible reason is that, aside from a lower fee, a $\mathrm{DAO}$ is not fundamentally different from old-fashioned book building by the underwriter if it is done in good faith. In theory, a traditional underwriter should seek out the same investors that would be attracted by a DAO. This suggests that underpricing may come from some source other than underwriter opportunism.

\section{OTHER ALTERNATIVES}

In addition to DAOs, there are several other alternative methods of going public that may address the underpricing problem in one way or another.

First, one obvious alternative is for the issuer to do a direct offering of shares without retaining the services of an underwriter. ${ }^{31}$ Such do-ityourself offerings were virtually impossible before the advent of the internet, but several issuers have attempted such direct offerings via the internet. The problem with a direct offering (according to conventional wisdom) is that investors do not like offerings without underwriters who are committed to supporting the stock after the offering. There are really two arguments here. One is that investors depend on underwriters as reputational intermediaries to vouch for the quality of the subject stock. The other is that investors dislike stocks for which there is no assured aftermarket. An underwriter is effectively committed to making a market in

Moreover, it may be that investors honor their bids in DAOs because they have been denied access to traditional (underpriced) IPOs.

${ }^{31}$ See Anita I. Anand, The Efficiency of Direct Public Offerings, 7 J. SMALL \& Emerging Bus. L. 433 (2003); William K. Sjostrom, Going Public Through an Internet Direct Public Offering: A Sensible Alternative for Small Companies?, 53 FLA. L. REV. 529 (2001). 
a stock it offers. If the underwriter ceases to make a market, it is likely that the price will collapse and the underwriter (as well as the issuer) will become the target of an action under the 1933 Act. In contrast, even if the issuer has arranged for a market maker in connection with a direct offering, there is no assurance that the market maker will support the stock forever. ${ }^{32}$

Second, some companies seek to go public by means of a reverse merger. In a reverse merger, the company that wants to go public finds a publicly traded shell company (or possibly a company that is publicly traded that wants to go private) and enters into a merger agreement with the shell company in which the shell issues a large number of shares to the subject company. For example, suppose that Acme Fireworks Corporation is a publicly traded company with one million shares of public float. Acme conducts a minimal business and it trades at about one dollar per share. Binford Tools Corporation wants to go public but does not want to undertake the expensive and time-consuming registration process required by federal law. Acme and Binford enter into a merger agreement whereby Acme will be the surviving company and will issue nine million shares to Binford stockholders as consideration. (Acme also agrees to change its name to Binford.) When the smoke clears, old Binford stockholders own nine million shares of new Binford, which is now publicly traded with a float of one million shares. (To complete the deal, new Binford might split off the old Acme business in exchange for whatever shares were held by the controlling stockholders of old Acme, after which Acme would be a private company wholly owned by its old controlling stockholders. Reverse mergers are sometimes called going public through the back door. Such deals have a dubious reputation, though it is not really clear why. No investors are typically harmed in the process if no new funds are raised, but for some reason avoiding the 1933 Act registration process has given the reverse merger a bad name even though the surviving company must immediately register as a public company under the 1934 Act and provide most of the same information that would have been required in a 1933 Act registration statement anyway. To be sure, the subject company need not comply in advance with federal securities law as a condition of becoming a public company. But the 1933 Act is supposed to be a disclosure statuteone with which any company can comply simply by telling the facts. Thus, it may be that the reputation of reverse mergers is mostly the product of badmouthing by traditional investment banks. ${ }^{33}$

\footnotetext{
${ }^{32}$ Incidentally, this is yet another way in which the 1933 Act has ossified the securities business and heightened barriers to entry. On the other hand, it is not clear that it is necessary to compel someone to make a market in a stock. It may be that market makers will seek out just about any stock that needs a market made. But as far as the issuer is concerned, it may seem too risky to leave such matters to chance.

${ }^{33}$ In the late 1990s, the SEC cracked down on reverse mergers indirectly by requiring that all companies listed for public trading be registered under the 1934
} 
Third, another alternative means of making a public offering is a private investment in public equity (PIPE). ${ }^{34}$ In a typical PIPE deal, a company that needs capital sells a large block of stock to an investment bank, hedge fund, or private equity group by means of an exempt private placement. The buyer holds the stock for some time and then registers it for sale as a secondary offering - an offering by a selling stockholder. The trick is (or was) that the SEC does not closely scrutinize such secondary offerings. The issuer in a PIPE deal is usually already publicly traded but is small and thinly traded-has relatively few shares outstanding in the hands of outside investors. Indeed, if an issuer has $\$ 75$ million in public float, it would likely qualify to use Form S-3 and would be able to file a shelf registration for a dribble out at-the-market offering. Thus, companies that do PIPEs are by definition companies with less than $\$ 75$ million in equity outstanding. ${ }^{35}$ PIPEs are associated with reverse mergers because many of the same securities firms handle the two types of transactions. Moreover, it is common for a reverse merger to be combined with a PIPE transaction. ${ }^{36}$

Fourth, yet another way for a company to go public is to give away stock for free or minimal consideration. Several companies in recent years have sought to give away their stock for free or in exchange for minimal consideration such as visiting an internet site or registering on the site. ${ }^{37} \mathrm{~A}$

Act irrespective of size - whether or not the company has 500 or more stockholders or $\$ 10$ million or more in assets. It remains possible for unregistered companies to be traded in the pink sheets. It is not clear whether the new rules have discouraged reverse mergers, because a company seeking to go public by such means would almost always plan to register under the 1934 Act anyway.

${ }^{34}$ See generally William K. Sjostrom, PIPEs, 2 ENTREPREN. BUS. L.J. 1 (2007).

${ }^{35}$ The SEC has also sought to rein in the use of PIPEs by limiting the number of shares that it will permit to be registered as a secondary offering. Whereas it was common up until 2006 for a secondary offering to include several times the number of shares outstanding prior to the offering, the SEC now limits secondary offerings to no more than one-third of the number of shares the issuer has outstanding. See Gregory Sichenzia, Presentation at the unpublished presentation at this symposium: IPOs in the Internet Age (March 2, 2007); Judith Burns, SEC Slows Flow of PIPE Deals to a Trickle, WALL ST. J., Dec. 27, 2006, at C1.

${ }^{36}$ PIPEs have also been associated with some arguably questionable tactics. In some cases, buyers in PIPEs transactions sell short the stock they buy in the private placement arguably driving down the price. In many PIPEs deals, the issuer agrees to a formula that requires the transfer of more shares for the same agreed consideration if the shares trade at a lower price-sometimes called a death spiral deal. In some such deals, buyers have been known to sell short many more shares than are even outstanding, raising questions about whether the short sales can be covered and are therefore legal. Of course, if the buyer has the right to buy more and more shares as the price declines, the short sales can be covered accordingly. ${ }^{37}$ Gregory Zuckerman, SEC Clears Web Firms' Stock Giveaway, WALL ST. J., Nov. 16, 1999, at C1; Scott Thurm, SEC Questions Start-Ups' Cheap Stock Sales to Customers, WALl ST. J., Sept. 26, 2000, at C1:3 (discussing use of stock rather than cash to pay for goods and services and thus augment earnings). Denis T. Rice, 
stock giveaway may seem a strange idea at first, but the cost of a public offering (in the form of fees, expenses, discounts and underpricing) is likely to be about $30 \%$ of the proceeds. So if one can establish a public market by giving away stock worth some amount less than that, it makes sense to do so. One can then return to the market later-after the stock is seasoned and an efficient price has been established - to raise capital.

Fifth, there are several regulatory schemes that can be used by smaller businesses to make public offerings. SEC Regulation A permits offerings of up to $\$ 10$ million using a much simplified registration scheme that also omits many of the restrictions and potential liabilities that attend a full-blown registration. ${ }^{38}$ SEC Rule 504 permits offerings of up to $\$ 1,000,000$ without federal registration if the offering is registered in one of the states. ${ }^{39}$ Regulation S permits off-shore offerings of stock if the stock is held off-shore for at least one year. ${ }^{40}$ And the London Stock Exchange Alternative Investment Market ("AIM") provides a much simplified offering process geared to the needs of small issuers. ${ }^{41}$

Free Stock on the Internet Is Not a Menace, 13 Insights, No. 9, at 8, Oct. 1999. This is not necessarily an internet phenomenon. Rather, it has only been made practical by the internet. For an older example of a similar tactic, see SEC v. Datronics Engineers, Inc., 490 F.2d 250 ( $4^{\text {th }}$ Cir. 1973).

${ }^{38}$ Regulation A has not been widely used. See Rutheford Campbell, Regulation A: Small Businesses' Search For "A Moderate Capital," 31 DEL. J. CORP. L. 77 (2006). It is not clear why. It may be that an underwriter is necessary and offerings are too small. See also Anita I. Anand \& Lewis D. Johnson, The Role of Underwriters in Nontraditional Offerings: Empirical Evidence, Queen's Univ. Law \& Economics Paper No. 2005-05 (April 2005); Christine Hurt, Initial Public Offerings and the Failed Promise of Disintermediation, 2 ENTREPREN. BUS. L.J. 703.

${ }^{39}$ See Sjostrom, supra note 32.

${ }^{40}$ In practice Regulation S works much like a PIPE deal, but the one-year off-shore holding period for equity securities makes impractical by comparison. See Richard Cameron Blake, Advising Clients on Using the Internet to Make Offers of Securities in Offshore Offerings, 55 Bus. LAW. 177 (1999). See also Stephen J. Choi, The Unfounded Fear of Regulation S: Empirical Evidence on Offshore Securities Offerings, 50 DUKE L.J. 663 (2000); Stephen J. Choi, Resales of Offshore Securities into the United States: Evaluating the Overvaluation Risk to U.S. Investors, 78 WASH. U. L.Q. 519 (2000). ${ }^{41}$ See generally Dale A. Oesterle, The High Cost of IPOs Depresses Venture Capital in the United States, 1 ENTREPREN. BUS. L. J 369, 376-78 (discussing AIM market in detail). There have been numerous efforts in both the U.S. and elsewhere to establish special markets for emerging companies, but none has been as successful as the LSE AIM. Most AIM listed companies go public by means of an offering to a select group of institutional investors. The cost of an offering is about 40 percent of an offering in the United States and takes eight to twelve weeks rather than the six to eight months required to do an offering in the United States. And there is little problem of underpricing (possibly because shares are placed with institutional investors). One reason that offerings are cheaper on AIM is that there is no underwriter as such. Rather, each company must retain a nominated advisor (NOMAD) who conducts due diligence and vouches for the suitability of the company to be listed on AIM. The NOMAD effectively performs the certification 
Finally, although it is not really a different technique, one way to minimize the cost of underpricing is to minimize the number of shares one offers as part of a traditional IPO. Assuming that an IPO will be underpriced, it clearly makes sense for a company to offer as few shares as possible to establish a market price and then to sell more shares in a followon offering. ${ }^{42}$ In other words, smaller offerings may themselves be a reaction to underpricing. ${ }^{43}$ If an issuer can establish a public market by offering a minimal number of shares, the issuer can then return to the market with another offering after the market establishes a price for the shares. There should be no danger of a price pop in a subsequent offering. If anything, the worry is that the price of the shares may decline because of increased supply. This would suggest that over time or in particularly active IPO markets, the percentage of shares offered should tend to decline. ${ }^{44}$

It is noteworthy that these methods mix and match the benefits of going public in different ways. Although it is common to think of an IPO as a way for the issuer to raise capital, an IPO is also a way to gain access to liquidity, which (among other things) may permit insiders to cash out. Indeed, these two functions can be combined variously in a traditional IPO. Although most traditional IPOs are exclusively of shares being sold by the issuer, it is quite common for a traditional IPO to include shares being sold by stockholders (particularly VC stockholders). Of the alternatives described above, both the reverse merger and the stock giveaway are deals that are designed solely to gain access to the market. Neither method raises capital for the company though both might make it easier for the company to raise capital in the future by means of a subsequent offering. These deals seem to confirm that there is value in access to the market beyond the

function of a US underwriter but without the need to put capital at risk. In addition, AIM has limited and modest listing requirements. AIM has been quite successful with 335 IPOs in 2005 compared to 35 on NASDAQ. The average AIM offering was $\$ 18.7$ million compared to $\$ 117.5$ million on NASDAQ. And although AIM companies are smaller than NASDAQ companies, they sport higher valuations, suggesting that AIM investors are willing to take more risk. There are approximately 2500 companies listed on AIM.

${ }^{42}$ Suzanne McGee \& Terzah Ewing, 'Piggyback' Deals: Keys to Unlock Insiders' IPO Stakes, WALl ST. J., February 17, 2000, at C1:3.

${ }^{43}$ It may be, too, that investors assume more risk that the price will be incorrect if the offering is relatively small and that therefore a bigger pop is required to be built into the price. Or it may be that underwriters find it inherently more difficult to price a smaller offering.

${ }_{44}$ Daines and Klausner assembled data for 310 IPOs during the period 1994 to 1997. During that period, the average offering was for $35 \%$ of outstanding shares and about $12.3 \%$ of that was sold by selling stockholders. See Robert Daines \& Michael Klausner, Do IPOs Maximize Firm Value: An Empirical Study of Antitakeover Protections, 17 J.L. ECON \& ORG. 83 (2001) (Table 1). In the thirty-four October 1999 IPOs studied here, the average offering was for $19.8 \%$ of the shares. 
capital one can raise in a public offering. On the other hand, the direct offering and the PIPE seem to be more about raising money than they are about establishing a market.

\section{Why AN INITIAL PUBLIC OFFERING?}

The foregoing illustrates that there are many reasons for going public and being public. This suggests that how the market reacts to the offering and the first day price pop may be related to the reason for an IPO. So the question is why do firms go public?

First, firms go public to raise equity capital. But, as noted above, this cannot be the only reason for going public, because often firms go public without raising any capital at all. Moreover, there are many other sources of equity capital, including venture capital firms and private equity firms. And that is not to mention debt financing. Moreover, it is quite expensive to raise equity capital by means of an IPO. As suggested above, the total cost of an IPO is probably about $30 \%$ of the offering amount on average. And it is not cheap to remain public thereafter. The indirect expenses of being public such as exposure to stockholder lawsuits and management distraction are also significant (even when discounted by probability). Finally, a public company must generate market returns for its stockholders that historically average about $15 \%$ at the median and even more for companies in riskier lines of business. ${ }^{45}$ For all this, the company gets the benefit of whatever capital it raises in the IPO, while the gains go to the stockholders. It is difficult to believe that this can be a good deal for many issuer companies. So there must be other benefits of going public by means of an IPO, and they must be quite significant. After all, an initial public offering is never a last ditch option. If anything it is a first ditch option.

Second, one of the primary benefits of going public is that it permits insiders to cash out of the business. One might think that the market would dislike this motivation because insiders will presumably want to sell high. On the other hand, the ability to bail out goes with the territory. Once a company is publicly held there is really no way to prevent insiders from selling at an opportune time. Still, one might expect offerings to include some sort of assurance that insiders will retain their interests (beyond lockups designed to control trading in the immediate aftermarket). To the contrary, however, it is common for offerings to include shares to be sold by existing stockholders. Surprisingly, secondary offerings (offerings by selling stockholders rather than by the issuing company) tend to perform better than offerings in which the money actually goes to the company. ${ }^{46}$

\footnotetext{
${ }^{45}$ See Ibbotson Associates, SBBI 2004 YEARBOOK, Table 2-1 (arithmetic mean return for stocks during the period 1926 to 2003 was $12.4 \%$ for large company stocks and 17.5 percent for small company stocks).

${ }^{46}$ Inmoo Lee, Do Firms Knowingly Sell Overvalued Equity?, 52 J. Fin. 4 (Sept. 1997) (finding that among seasoned issuers, companies offering additional stock by selling
} 
This finding is somewhat counterintuitive in that one would think investors would be suspicious of offerings by which existing shareholders seek to bail out of their own investments rather than to raise money for the company. But there is an alternative explanation for why an insider would want to bail out. Insiders are generally underdiversified. Typically, a large percentage of an insider's portfolio is invested in the subject company in part because the insider cannot easily sell. Moreover, if the insider is actively involved in the management of the company, he also has much of his human capital invested in the same place. Going public permits insiders to diversify their holdings and reduce risk without any sacrifice of expected return. That constitutes a gain. And it is a gain that does not depend on any change in the price of the subject company stock. In other words, it does not necessarily follow that just because an insider seeks to sell, he expects the price of the stock to go down. Indeed, given the legal sanctions that attend fraudulent offerings and insider trading, the urge to diversify is a much more likely explanation for going public. ${ }^{47}$ In addition, although shares offered by stockholders presumably reduce the capital available to the company (on the theory that the company can only support so much outstanding stock), it may be that investors are suspicious of companies that need equity capital. Perhaps investors figure that a company with good prospects ought to be able to raise capital privately or in the debt market and, therefore, that establishing a trading market for the company's shares is the most believable reason for going public. ${ }^{48}$

stockholders perform better than companies offering additional stock for the company account). But see Danielle Sessa \& Terzah Ewing, Some Insiders Sell Shares at Time of IPO, WALL ST. J., Sept. 1, 1999, at C1. It is possible that secondary offerings do better because they are discounted from the beginning. See also Carol A. Marquardt \& Christine I. Wiedman, Voluntary Disclosure, Information Asymmetry, and Insider Selling Through Secondary Equity Offerings, 15 CONTEMP. ACCT. RES. 505 (1998) (finding that disclosure tends to be better in connection with secondary offerings). $C f$. Stephen J. Choi, The Informational Effect of an Offshore Securities Offering: Evaluating the Risk to U.S. Investors, 78 WASH. U. L. Q. 519 (2000).

${ }^{47}$ There are numerous examples of diversification as a motivation. In 1966, the popularity of swap funds induced amendment to section 351 the Internal Revenue Code, 26 U.S.C. $\$ 351$ (2006), making such transactions taxable on the theory that an investor enjoys a gain from diversification. And in the 1990s, the SEC adopted Rules $10 \mathrm{~b}-5(1) \&(2)$ in part to provide a safe harbor for insider sales pursuant to standing orders, on the theory that such sales are legitimately motivated by insiders' seeking diversification.

${ }^{48}$ Catch 22 comes to mind. One might also characterize resistance to companies that need capital as a reverse Groucho Marx effect. That is, maybe the market likes only companies that do not much need the market. This is consistent with the fact that more stock is bought back in the aggregate during most years than is sold to the public. It may also be the case that many secondary offerings are made by venture capital investors and that their earlier involvement with the company signals to the market that the company's prospects are better. If so, there should be 
Third, being publicly held permits a company to use equity as compensation. $^{49}$ To be sure, the use of options as compensation has developed a dicey reputation in recent years ultimately because it is seen as diluting the interests of outside investors. But the use of options (and stock) as compensation also has the effect of supporting stock price going forward. Options are attractive only if the recipients think that stock price is likely to increase over the long haul. So the use of options as a significant component of compensation has a bonding effect. Moreover, it is common practice among companies that use equity as compensation to repurchase outstanding shares to control for dilution. Otherwise, when options are exercised, the number of outstanding shares will increase and earning per share will decrease. ${ }^{50}$ So options also induce issuers to distribute cash to the market and to do so in a way that has the biggest bang for the buck-by buying back the shares of the least optimistic stockholders.

Fourth, some companies go public because they have no choice. In many cases, venture capital investors require investee companies to go public or sell out by a specified date. And sometimes successful companies that have used equity as compensation find that the population of stockholders grows to the point that the company must register with the SEC as a public company. For example, Google decided to make a public offering of its stock in large part because it was required to be public under SEC regulations.

some correlation between particular venture capital investors and aftermarket performance.

${ }^{49}$ See, e.g., Kaufmann v. Lawrence, 386 F. Supp. 12 (S.D.N.Y. 1974) (company went public primarily to use equity compensation and went private because market price stagnated).

${ }^{50}$ In addition, being publicly held gives a company access to market pricing which in turn provides important feedback to management. To be specific, management may look to the reaction of the market to help decide if its strategies are on track. One might call this the Ed Koch How Am I Doing effect. This is a variation on the notion that the market acts to discipline public companies. But in this setting, the idea is that some companies seek out the discipline of the market. For example, market feedback may be quite important in conglomerate companies with disparate lines of business where middle managers may not fully appreciate the value added by each other's efforts. On the other hand, one of the fundamental problems faced by such companies is that equity compensation does not work especially well when results are less clearly tied to one's efforts. Indeed, it might be tempting for the management of one division to slack off and free ride on the efforts of other divisions. It seems unlikely that this factor alone would ever be a reason to go public. Indeed, some might say that the need to deal with the market is one of the big downsides of being public. Nevertheless, plenty of companies that could go private choose to remain public. So it may be that in some settings it is important to have the market as an arbiter. At the very least, the CEO can use the market as an excuse for difficult decisions. Cf. Bernard S. Black, Information Asymmetry, the Internet, and Securities Offerings, 2 J. SMALL \& EMERGING Bus. L. 91 (1998) (discussing Netscape's solicitation of VC investors not for the capital but rather for added legitimacy in advance of IPO). 
The above reasons for going public and for being public are not mutually exclusive. Indeed, it is possible (if not common) for an IPO to be motivated by varying combinations of all of these reasons, although one reason or another may predominate and affect the reception for an IPO. For example, the market may prefer companies that offer a relatively large percentage of shares to the public on the theory that the company will be more exposed to takeover and the discipline of the market. It is also possible that the reason for the offering affects the way it is done. Sometimes the effect may be obvious, as where the offering explicitly includes a large number of shares offered by stockholders. But in other situations, the reason for the offering may be difficult to divine. For example, if the company offers relatively few shares, it may plan to offer more in the future. So the market may discount the shares in the IPO.

\section{A. The Evidence}

Although numerous explanations have been offered for the apparent systematic underpricing of IPOs, there has been relatively little investigation of whether underpricing can be correlated with the terms of an offering. ${ }^{51}$ The question is: Are there any identifiable factors that cause the market to bid up the price of some IPOs more than others? In order to see whether and how the reason for an IPO affects market reception, I gathered data for the thirty-four IPOs conducted during October 1999. I limited the period to one month in order to avoid differing market conditions that could affect market reception. ${ }^{52}$ Moreover, it may be that offering terms evolve

\footnotetext{
${ }^{51}$ Robert Daines and Michael Klausner, supra note 45; See also Steven Lipin, Firms Incorporated in Delaware Are Valued More by Investors, WALL ST. J., Feb. 28, 2000, at C21; Frank Easterbrook, International Corporate Differences: Markets or Law, J. APPLIED CORP. Fin., available at htt[://papers.ssrn.com/sol13/papers.cfm?abstract_id=8179 (Winter 1997); Rafael LaPorta, Florencio Lopez-de-Silanes, Andrei Shliefer \& Robert Vishny, Legal Determinants of External Finance, Working Paper No. 5879 (Jan. 1997) (finding that stronger legal protections of common law countries lead to stronger stock market than in civil law countries); The Law of the Market, ECONOMIST, Apr. 19, 1997, at 78 (discussing LaPorta study). But see John C. Coffee, Jr., Convergence and its Critics: What are the Preconditions to the Separation of Ownership and Control? (unpublished manuscript); John C. Coates IV, Explaining Variation in Takeover Defenses: Failure in the Corporate Law Market (unpublished manuscript) (both finding diminishing differences between two systems). See generally Antonio S. Mello \& John E. Parsons, Auctions of Shares with a Secondary Market and Tender Offers, CEPR Discussion Paper No. 1077 (Dec. 1994) (arguing that method of sale of company, whether through IPO or negotiation, is or should be a result of competition among various types of investor buyers).

${ }^{52}$ These thirty-four IPOs occurred from Oct. 1 to Oct. 26, during which period the S\&P500 went from 1282.81 to 1281.91 with an interim high of 1335.21 on Oct. 11
} 
during a wave of IPOs. For example, companies may be able to offer smaller and smaller (or larger and larger) percentages of shares as an IPO market evolves. So in order to compare apples to apples it is important to limit the sample to a short time span in which all issuers face the same conditions. Needless to say, October 1999 was near the height of the dotcom boom and the irrational exuberance that went with it. The upside is that this single month offers a relatively large sample of deals. The downside is that October 1999 is not a typical month. But the point is to compare the terms of IPOs during that month with each other. So the particular month may not matter much.

The accompanying chart sets forth data for the October 1999 IPOs. In addition to the issuer name and ticker, the underwriter, and the date of the offering, the chart shows the offering price, the first day closing price, the first day price pop as a percentage of the offering price, the number of shares offered, the number of shares outstanding after the offer, the number of shares offered as a percent of outstanding after the offer, the number of additional shares that the underwriters may buy pursuant to option (the socalled Green Shoe Option or simply the shoe in Street lingo), the number of options outstanding, the reserve for additional options, the total number of shares outstanding assuming exercise of all options, and the fully diluted market capitalization assuming exercise of all options. ${ }^{53}$

and an interim low of 1247.41 on Oct. 15 . The S\&P500 closed on the last trading day of the month, Oct. 29, at 1362.93 .

${ }^{53}$ A Green Shoe Option (or overallotment option) permits an underwriter to buy up to $15 \%$ more shares from the issuer than the number stated in the offering. Although one might think that the rationale for having a shoe in the deal is that it permits the underwriter to cash in on a price pop in the aftermarket, the underwriter is precluded under the 1933 Act from selling shares at a higher price than the offering price. The real reason for a shoe is to permit the underwriter to sell the additional $15 \%$ in the first place. For example, in a deal involving the issue of 10 million shares, suppose the underwriter sells 11.5 million shares. The underwriter is effectively short by 1.5 million shares. If demand for the IPO shares remains strong in the aftermarket, the underwriter can exercise the green shoe option and cover its short position. If demand is weak, the underwriter can buy back shares using the proceeds from the sale of the 1.5 million shares - which did not really exist in the first place- to keep the market price from falling below the offering price. In other words, the idea is to oversell the deal on purpose, which may also explain to some extent why IPO prices tend to rise. This option is usually called a Green Shoe Option (after the offering in which it was originally used) or a Green Shoe or simply a shoe. Most underwriting agreements include a shoe for the maximum 15 percent and, typically, for the maximum of 45 days following the offering date. There can be some thorny issues as to who should supply the shares for a shoe. Again, the underwriter will only exercise the shoe if the shares increase in price. Thus, individual stockholders will not want the shares to come out of their holdings. The underwriter and institutional stockholders may be averse, however, to the potential for further dilution. And where there are distinct groups of stockholders such as founders and various levels of VC investors, one group may prefer to see other stockholders give up their shares rather than have the company issue additional shares. Thus, the underwriting agreement should be clear as to who must provide the additional 
The last two columns show money on the table (in millions of dollars) and money on the table as a percent of total outstanding shares. The phrase money on the table refers to the dollar value of the first day price pop times the number of shares offered (not including the shoe). This is the additional amount that the issuer could have raised if all of the shares offered had been sold at the first day closing price - the total dollar amount of underpricing. The last column shows total underpricing as a percentage of fully diluted market capitalization. Thus, the chart is designed primarily to permit comparison of various aspects of the offerings to the first day price pop.

In addition to the above data, the appendix lists the stated reasons for the IPOs in the study as taken from the prospectus summary for each.

\section{B. Analysis}

The data indicate that there may be an inverse correlation between offering size (as a percentage of total outstanding shares) and the size of the first day increase in stock price. ${ }^{54}$ In other words, smaller percentage offerings tend to generate a bigger pop than do larger percentage offerings. 55

shares, and how the burden will be shared if the option is exercised as to some but not all of the shares. It is interesting that the standard shoe is $15 \%$ of the planned offering which is roughly equal to the average first day price pop. For data about shoe use, see Randall S. Thomas \& James F. Cotter, Are Firm Commitment Underwritings Risky? The Role of the Over-Allotment Option (Feb. 1998) (unpublished manuscript) (finding that over-allotment option is used to decrease risk and increase profits in successful offering).

${ }^{54}$ This hypothesis is based on a study of 34 IPOs occurring during October 1999 . To be sure, much has happened in the markets since then, including the dotcom bust and numerous corporate scandals that began with the collapse of Enron. Moreover, one might argue that October 1999 was at the height of the dotcom frenzy and thus is likely to be highly idiosyncratic. On the other hand, the IPO market has not been nearly as active since the end of 2000 as it was for the six years ending in 2000. So recent markets may be atypical too. Moreover, there have been numerous hot issues markets over the years, and there is every reason to believe that there will be more. Indeed, the reason for limiting the study to one month is that market conditions may change over a longer period. I chose October 1999 because it was relatively late in the 1995 to 2000 period and presumably reflected practices that had become fairly standardized. Moreover, I chose October because (except for periodic market crashes) it tends to be a business-as-usual month unaffected by summer vacations or holidays. See e.g., Anand, supra note 1 (discussing unusual conditions in 1999 IPO market).

${ }_{55}$ There are several different ways to measure and interpret this data. For example, it is unclear precisely how to measure the amount of stock outstanding. Should one include shares that have been reserved for employee stock option plans? In addition, companies often go public by selling lesser voting stock to the public. Does the total number of votes of the shares being sold compared to the total voting power affect performance in 
One possible explanation for why smaller percentage offerings show a bigger first day pop is simple supply and demand. ${ }^{56}$ In other words, the fewer the number of shares offered, the more intense the competition for them. As I have argued elsewhere, downward sloping demand may explain underpricing of IPOs generally. That is, given that IPOs are typically sold by means of a fixed price offering, the price of the offering must be set low enough to induce the least optimistic buyer to buy. And given that the stock must be widely distributed (both legally and practically), it seems likely that many optimistic investors will get fewer shares than they would like to get. ${ }^{57}$ It is not clear, however, why supply and demand should work disproportionately in favor of smaller offerings. Moreover, one would think that the absolute number of shares available would be more important than the percentage of shares offered. It is also possible that the small size of an offering signals to the market that insiders are more confident about the business and want to retain more shares or that they hope for a subsequent offering at a higher price. ${ }^{58}$ But neither of these

the aftermarket? What proportion were internet stocks? Is there a lockup correlation? Is size of pop correlated with longer term gain?

${ }^{56}$ Floyd Norris \& Lawrence M. Fisher, Offspring Outweighs Parent as Offering Hits the Market, N.Y.TIMES, March 3,2000, at A1:4 (describing offering by $3 \mathrm{Com}$ of shares in Palm, Inc., a 94 percent subsidiary after the offering: "The soaring price for Palm partly reflected the fact that less than 5 percent of the outstanding shares were available for trading, far from enough to satisfy investor demand"). Terzah Ewing \& Joshua Harris Prager, Many Are Finding IPOs Still Out of Reach, WALL ST. J., February 28, 2000, at C21:1 (discussing difficulty of small investors in getting access to IPO shares).

${ }^{57}$ Lockups may also have the effect of minimizing supply. One recent study indicates that offerings with lockups maintain a higher price in the aftermarket, though the difference was minimal with internet IPOs. See Danielle Sessa \& Terzah Ewing, Some Insiders Sell Shares at Time of IPO, WALL ST. J., Sept. 1, 1999 , at Cl. The study is somewhat flawed in that it appears to include all year 2000 IPOs through August 30, 2000, thus including offerings made under differing conditions and with radically different time on the market for seasoning. What does a lockup signal to the market? Does market react differently to offerings by selling stockholders than it does to unlocked shares? What difference does a lockup make if the stockholder cannot sell until one year later anyway under Rule 144? See Royce de Rohan Barondes, Adequacy of Disclosure of Restrictions on Flipping IPO Securities (2002) (Working Paper), available at http://papers.ssrn.com/sol13/papers.cfm?abstract_id=173248.

${ }^{58}$ See Ronald J. Gilson, Evaluating Dual Class Common Stock: The Relevance of Substitutes, 73 VA. L. REV. 807 (1987) (discussing distinction between growth companies and cash cows). Several of the IPOs in the sample consisted of lesser voting stock. This did not seem to affect the market reception for the stock, suggesting that investors do not particularly care about voting rights or the potential for a change in control. Gilson has suggested that lesser voting stock may not matter in the context of a growth company because management interests are similar to stockholder interests. Id. See also Jeffrey N. Gordon, Ties That Bond: 
theories explains why an underwriter would fail to adjust the price of a smaller percentage offering upward so as to avoid underpricing to the extent possible. In other words, one would think that underwriters would consider the quantity of stock to be sold in pricing the issue in the first place. $^{59}$

Another possible explanation for the excess price increase of smaller offerings is that the market effectively charges a more or less fixed amount for liquidity as a percentage of market capitalization. If so, one would expect this liquidity charge to be a larger proportion of smaller offerings - a larger pop. Indeed the data suggest that there may be some truth to this explanation. As the last column of the chart shows, money on the table tends to be relatively stable as a percentage of market capitalization.

This explanation for (supposed) IPO underpricing raises more questions than it answers. It suggests that somehow the market adjusts for offering size and market capitalization irrespective of the absolute number of shares being offered. In other words, a small company that offers a large number of shares will give up about the same percentage of its post-offer market capitalization as will a big company that offers a small number of shares. How and why would the market make such a strange adjustment?

One possible answer is that the first day price pop has been misinterpreted. Although the first day price pop is generally assumed to be the result of underpricing, it is ultimately an ambiguous piece of information. It is at least conceivable that a price pop occurs in offerings that are properly priced. In other words, it may be that an offering at a

Dual Class Common Stock and the Problem of Shareholder Choice, 76 CAL. L. REV. 11 (1988). Ironically, lesser voting stock would not have been a possibility before the adoption of Rule $19 \mathrm{c}-4$, a rule designed to protect stockholder democracy, which was subsequently struck down in Business Roundtable v. SEC, 905 F.2d 406 (D.C. Cir. 1990), as beyond the authority of the SEC. Before the adoption of the rule, a company with lesser voting stock could not be listed on the NYSE. Thus, practically speaking, a company that aspired to be listed on the NYSE at some later point would have needed to comply with NYSE rules or undergo a messy recapitalization before being listed on the NYSE.

${ }^{59}$ It is possible that as of October 1999, underwriters had not figured out downward sloping demand and how to adjust for it in connection with relatively small offerings, but it seems unlikely. The Dutch Auction is founded on the notion that the quantity offered is inversely related to the market clearing price. The Dutch Auction has been around for years and has been used extensively in connection with issuer repurchases since the early 1980s. Moreover, the Dutch Auction model has more recently been used by Wit Capital and Hambrecht \& Company precisely in an effort to avoid underpricing in connection with IPOs. In short, it is inconceivable that underwriters are not aware that quantity is arguably a key factor in establishing the offering price. Some stock exchanges require that a minimum percentage of shares be offered to the public. For example, the Neuer Markt requires minimum of ten percent of stock to be sold unless stock meets an aggregate value standard. 
higher price would fail to sell out, whereas when properly priced, the offering sells out and-in a quantum mechanical jump-pops in price. Indeed, the fact that several DAOs have experienced substantial price pops suggests that some such other force may be at work. Call it the dark matter of the market. ${ }^{60}$

To be specific, it is possible that an IPO is something like a tender offer in reverse. Virtually all tender offers involve a premium over the market price. On average, the premium is about $50 \%$ of the pre-offer price. Although takeover premiums are usually thought to arise because the target company has been mismanaged or because the bidder perceives the possibility of gain through various changes in management, it is also arguable that target stockholders require a premium simply in order to be induced to tender. While some have argued that in an efficient market composed primarily of diversified investors, any premium should be enough, it is difficult to imagine that an offer at a minimal premium would induce many stockholders to tender their shares. ${ }^{61}$ In the context of an IPO, it may be that investors will not buy a stock that is fully priced and will not then sell that stock unless they can do so at a gain. This may be nothing more than another example of the well-documented tendency to place a higher value on something one owns than on something one might buy. ${ }^{62}$

Discounts (and premiums) may also be the result of downward sloping demand for individual stocks. ${ }^{63}$ Although a diversified investor who holds a portfolio of many stocks is a price-taker in a normal market, the same investor may behave more like an undiversified investor in the context of a takeover bid where it is clear that the bidder perceives that the deal will generate financial gain. To be sure, a rational investor should eschew stock picking and prognostication on the basis of company-specific fundamentals. In other words, a rational investor should ordinarily pay

\footnotetext{
${ }^{60}$ Moreover, the first day closing price is the price paid by the most optimistic investor. There is no reason to think that all of the shares in the offering could have been sold for that price. So it is not clear that total underpricing is equal to the price pop multiplied by the number of shares offered. This point is well illustrated by DAOs. In a DAO, the highest bidding investors are usually rather small in number. There is no reason to think that the entire offering could ever be sold to the highest bidders. So there is no reason to think that the aftermarket could absorb all of the shares in the IPO at the closing price. As any market maker would agree, there is no such thing as single market price. Rather, there are various prices at which investors are willing to buy and sell various quantities of shares. Indeed, market technology reflects this fact.

${ }^{61}$ See Frank H. Easterbrook \& Daniel R. Fischel, The Proper Role of a Target's Management in Responding to a Tender Offer, 94 HARV. L. REV. 1161, 1168 (1981). The authors argue that premiums are as high as they are because the law distorts the market.

${ }^{62}$ This phenomenon may be quite central to the way financial markets work. For example, it may be the ultimate source of the bid-ask spread.

${ }^{63}$ See Richard A. Booth, The Efficient Market, Portfolio Theory and the Downward Sloping Demand Hypothesis, 68 N.Y.U. L. REV. 1187 (1993). Downward sloping demand may itself be the result of sticky valuation.
} 
little or no attention to the idea that this or that stock is underpriced or overpriced. But the situation is different when a company is in play. Although target stockholders may not know (or care) why a bidder perceives the possibility of gain, they do know that the bidder wants the target company. The bidder must think the target is worth more than the offer price. So target stockholders will hold out for a share of the gain. Indeed, studies indicate that most of the gain from takeovers goes to target stockholders in the form of premiums. ${ }^{64}$

Similarly, an investor who buys into an IPO may focus on the subject shares as if she were an undiversified investor. In a sense an investor is undiversified with regard to IPO shares because she is being asked to invest a substantial sum in a new stock without regard to her other portfolio holdings. Thus, a diversified investor may be willing to pay only the price that an undiversified investor would pay for the IPO stock. Once the offering has been completed, diversified investors can buy the shares to add to their portfolios. Because diversified investors assume no company specific risk (or risk that the offering may fail), they are naturally willing to pay more for the IPO shares in the aftermarket. It should come as no surprise that the shares rise in price. ${ }^{65}$ As in a tender offer, investors must assume that the issuer expects somehow to gain from an IPO. If so, investors will insist on some portion of the gain. Indeed, the average price pop is about $18 \%$ whereas the average takeover premium is about $50 \%$. There is no obvious reason why the sell-side premium in an IPO should be lower than the buy-side premium in a takeover - why the cost of entering the market should be less than the cost of exiting the market. Arguably, investment bankers do a pretty good job keeping down the price of going public.

Finally, what about the apparent relationship of price pop to total market capitalization? At first blush, it seems quite mysterious that there would be any such relationship at all. How does the market know? Why does it care? Again, the answer may relate to investor diversification. Many institutional investors weigh portfolios holdings according to the market capitalization of the issuer. It thus stands to reason that demand for a stock will be directly related to its market capitalization. ${ }^{66}$

\footnotetext{
${ }^{64}$ Moreover, the bidder in a tender offer must expect significant gains to overcome the disadvantage of being undiversified (or the implicit premium that diversified investors attach to portfolio stocks, which is the same thing). On the other hand, some bidders such as LBO firms may be somewhat diversified. It is possible that most DAOs involve companies that need money.

${ }^{65}$ A similar phenomenon occurs when a stock that is already publicly traded is added to a major index such as the S\&P500. Because major market indices are used by index funds (among others) as a model for their portfolios, addition to an index enhances demand for a stock and thus its price.

${ }^{66}$ It is not entirely clear that this approach to weighting makes sense. It might make more sense to weight according to public float. Some market indices and funds have adopted such a method recently. Indeed, some indices such as the Dow Jones Averages
} 


\section{CONCLUSION}

It is not at all clear from the data that the first day price increase seen in most initial public offerings is a result of underpricing. Rather, it is possible - if not likely - that the first day price increase is natural market phenomenon akin to a takeover premium. In addition, it may be that the price increase is the natural result of the incorporation of a new issue into the portfolios of diversified investors. Because diversified investors assume less risk than undiversified investors, they are willing to pay a higher price for each individual stock as part of a portfolio of numerous stocks. Moreover, because the market understands the value of diversification, they are willing to buy newly issued stock even though the offering may be motivated by the desire of insiders to cash out and themselves gain the advantages of diversification. But because the market understands that insiders stand to gain, issuers must effectively pay a premium by offering the stock for less than it is likely to be worth in the hands of diversified investors. As a result, pop goes the market.

do not weight stocks at all. But no matter how one measures market capitalization, weighting implies that the more a stock is worth the more of it the market will demand. This gives rise to positive feedback that magnifies changes in stock price in either direction. Indeed, one study during the dotcom frenzy found a strong logarithmic correlation between market capitalization and market prices for internet stocks. Presumably the same relationship would hold for any stock. 


\title{
IV. APPENDICES
}

\section{OCTOBER 1999 STUDY -- USE OF PROCEEDS}

Statements relating to use of proceeds are from the IPO Reporter or the prospectus as indicated.

\begin{abstract}
AETHER SYSTEMS
Prospectus: We intend to use approximately $\$ 14.8$ million of net proceeds to repay in full all indebtedness incurred under our senior secured interim credit facility with Merrill Lynch \& Co., one of the underwriters of this offering, of which $\$ 11.7$ million was used to purchase Mobeo, approximately $\$ 0.8$ million was used to pay fees and expenses related to the credit facility and the remaining $\$ 2.3$ million was allocated for general corporate purposes. In addition, we intend to use approximately $\$ 2.5$ million of the net proceeds to exercise a warrant to increase our ownership in OpenSky from $26 \%$ to up to $33 \%$ on a fully diluted basis and approximately $\$ 2.0$ million to expand our network operations center over the next 12 months. We currently intend to use the remaining net proceeds from the offering for general corporate purposes, which may include some or all of the following: enhance our sales and marketing activities; fund cash flow deficits and working capital needs; enhance Mobeo service offerings; fund potential future acquisitions; and maintain our interest in OpenSky.
\end{abstract}

\section{ALTIGEN COMMUNICATIONS}

Prospectus: General corporate purposes, including working capital.

\section{BREAKAWAY SOLUTIONS}

IPOR: To increase its visibility and strengthen its reputation in the marketplace; to enhance its ability to use stock for acquisitions; and to provide liquidity for the company's existing stockholders.

\section{CALICO COMMERCE}

IPOR: Primarily for general corporate purposes, including sales and marketing activities, product development and support and capital expenditures; \$3 million of the proceeds is earmarked for facilities improvements or acquisitions.

\section{CHARLOTTE RUSSE HOLDING}

Prospectus: We intend to use all of the net proceeds to repay substantially all of our secured indebtedness outstanding under our revolving credit facility.

\section{CROSSROADS SYSTEMS}

Prospectus: Working capital and other general corporate purposes, as well as capital expenditures, expansion of our marketing and distribution activities, research and product development, and potential acquisitions.

\section{CYSIVE}


IPOR: Obtain additional equity capital, create a public market for its common stock and facilitate future access to public markets; general corporate purposes, including working capital, expansion of operations and sales and marketing activities.

\section{DSL.NET}

Prospectus: To continue building our network and for working capital and other general corporate purposes. We may also use a portion of the proceeds to acquire complementary businesses.

\section{E-STAMP}

IPOR: Sales and marketing expenditures related to promoting the company's services; building the E-Stamp brand; and developing additional strategic relationships.

\section{HOMESERVICES.COM}

Prospectus: for (1) the continued development of its E-commerce operations, (2) working capital and (3) general corporate purposes, which include acquisitions of real estate brokerage firms and their related service businesses.

IGO

IPOR: Obtain additional capital, create a public market for the company's common stock and facilitate further access to public markets. iGo intends to use approximately half of the net proceeds for investment in sales and marketing, and the remainder for general corporate purposes, including working capital and capital expenditures, as well as possible strategic acquisitions or investments.

\section{ILLUMINET HOLDINGS}

Prospectus: to fund potential acquisitions; to develop new and improved services; to maintain and expand our network equipment and infrastructure; and for general corporate purposes.

\section{INTERTRUST TECHNOLOGIES}

Prospectus: General corporate purposes, including working capital.

\section{INTERWOVEN}

IPOR: Working capital and other general corporate purposes, including increased sales and marketing expenditures, increased research and development expenditures and capital expenditures.

\section{JNI}

Prospectus: repayment of indebtedness of approximately $\$ 4.3$ million to Jaycor, Inc., an affiliate; and working capital and general corporate purposes, including product development, sales and marketing and potential acquisitions of products, technologies or companies.

\section{JUPITER COMMUNICATIONS}

IPOR: Working capital.

\section{MARTHA STEWART LIVING OMNIMEDIA}


Prospectus: We may use approximately $\$ 41.8$ million of the net proceeds from this offering to purchase shares of Class A common stock held by Time Publishing Ventures, Inc., a subsidiary of Time Inc., under the terms of an existing agreement. We plan to use the remainder of the net proceeds of this offering for general corporate purposes.

\section{NAVISITE}

Prospectus: For enhancement and expansion of our network infrastructure, expansion of sales and marketing efforts, enhancement of application management and technical expertise, possible acquisitions of complimentary businesses and technologies and working capital and general corporate purposes.

\section{NETCENTIVES}

IPOR: Working capital and other general corporate purposes.

\section{NEUBERGER BERMAN}

IPOR: Repay a $\$ 50$ million subordinated note; and repay approximately $\$ 42$ million of short-term borrowings

PC TEL

Prospectus: $\$ 15.7$ million of the proceeds from this offering will be used to repay bank debt. The remaining proceeds will be used for general corporate purposes, including working capital, and for potential investments in and acquisitions of complementary products, technologies or businesses.

\section{PLANETRX.COM}

IPOR: For general corporate purposes, principally working capital and capital expenditures.

\section{QUICKLOGIC}

IPOR: General corporate purposes ( $\$ 20.9 \mathrm{mil}$.), additional proceeds will be used to make payments stemming from a legal dispute with Actel, as well as fund future acqusitions.

\section{RADIO UNICA COMMUNICATIONS CORP}

Prospectus: to prepay all indebtedness outstanding under our credit facility;for acquisitions and upgrades; for general corporate purposes and working capital requirements.

\section{RESOURCEPHOENIX.COM}

IPOR: Capital expenditures and general corporate purposes.

\section{SILICON IMAGE}

IPOR: Working capital and debt repayment.

\section{SMARTDISK}

IPOR: Research and development (\$6.1 mil.), sales and marketing (\$3.0) and capital expenditures (3.0 mil.).

\section{SYCAMORE NETWORKS}


Prospectus: for general corporate purposes, including working capital and capital expenditures, and the repayment of certain indebtedness.

TRIZETTO GROUP

IPOR: Expansion of sales and marketing activities; development of application services, Internet and connectivity technologies.

VIADOR

Prospectus: for general corporate purposes, including working capital, funding operating losses and approximately $\$ 7.0$ million to $\$ 10.0$ million for research and development in connection with our operations.

\section{VITAMINSHOPPE.COM}

IPOR: Net proceeds will be used for Web site improvement ( $\$ 7.5 \mathrm{mil}$.) and debt repayment ( $\$ 5.8 \mathrm{mil}$.)

\section{WILLIAMS COMMUNICATIONS GROUP}

Prospectus: We estimate that the net proceeds from the equity offering will be approximately $\$ 635.7$ million. We estimate that the net proceeds from the notes offering will be approximately $\$ 1.94$ billion and the net proceeds from the concurrent investments will be at least $\$ 725$ million. We intend to use these net proceeds, together with other borrowings and available funds, to develop and light the Williams network, repay portions of our debt, fund operating losses and for working capital and general corporate purposes

\section{WOMEN.COM NETWORKS}

Prospectus: To fund continued growth and expansion of our business, to build our brand both online and offline and to enhance our products. The balance of the proceeds will be used to fund potential acquisitions and for other general corporate purposes, including working capital.

WORLD WRESTLING FEDERATION ENTERTAINMENT

Prospectus: We intend to use the net proceeds of approximately $\$ 155.6$ million from the offering for working capital and other general corporate purposes. 



\begin{tabular}{|c|}
\hline$\sum_{\Sigma}^{W}$ \\
\hline VITAMINSHOPPE.COM \\
\hline RESOURCEPHOENIX.COM \\
\hline NEUBERGER BERMAN \\
\hline TRIZETTO GROUP \\
\hline HOMESERVICES.COM \\
\hline NETCENTIVES \\
\hline CHARLOTTE RUSSE HOLDINGS \\
\hline DSL.NET \\
\hline IGO \\
\hline WILLIAMS COMMUNICATIONS \\
\hline VIADOR \\
\hline E STAMP \\
\hline PCTEL \\
\hline WORLD WRESTLING FEDERATION \\
\hline ILLUMINET HOLDINGS \\
\hline QUICKLOGIC \\
\hline RADIO UNICA COMMUNICATIONS \\
\hline PLANETRX.COM \\
\hline ALTIGEN COMMUNICATIONS \\
\hline JUPITER COMMUNICATIONS \\
\hline WOMEN.COM \\
\hline MARTHA STEWART LIVING \\
\hline SMARTDISK \\
\hline $\mathrm{JNI}$ \\
\hline CYSIVE \\
\hline SILICON IMAGE \\
\hline INTERWOVEN \\
\hline NAVISITE \\
\hline BREAKAWAY SOLUTIONS \\
\hline INTERTRUST TECHNOLOGIES \\
\hline AETHER SYSTEMS \\
\hline CALICO COMMERCE \\
\hline CROSSROADS SYSTEMS \\
\hline SYCAMORE NETWORKS \\
\hline
\end{tabular}

\begin{tabular}{|c|c|c|c|}
\hline$\frac{\stackrel{\mathscr{U}}{\Psi}}{\underline{\underline{U}}}$ & 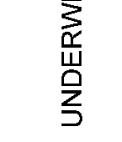 & $\underset{\square}{\mathbb{E}}$ & 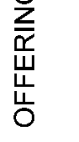 \\
\hline VSHP & TWP & 8-Oct & 11 \\
\hline RPCX & RS & 14-Oct & 8 \\
\hline NEU & GS & $6-$ Oct & 32 \\
\hline TZIX & BS & 7-Oct & 9 \\
\hline HMSV & USB/PJ & 8-Oct & 15 \\
\hline NCNT & CSFB & 14-Oct & 12 \\
\hline $\mathrm{CHIC}$ & RS & 20-Oct & 11 \\
\hline DSLN & DBAB & 6-Oct & 7.5 \\
\hline IGOC & RS & 14-Oct & 12 \\
\hline WCG & SSB & 1-Oct & 23 \\
\hline VIAD & BS & $25-O c t$ & 9 \\
\hline ESTM & DLJ & 8-Oct & 17 \\
\hline PCTI & BOAS & $18-O c t$ & 17 \\
\hline WWFE & BS & 18-Oct & 17 \\
\hline ILUM & MSDW & 7-Oct & 19 \\
\hline QUIK & RS & 15-Oct & 10 \\
\hline UNCA & SSB & 18-Oct & 16 \\
\hline PLRX & GS & 6-Oct & 16 \\
\hline ATGN & $\mathrm{CIBC}$ & 5-Oct & 10 \\
\hline JPTR & DLJ & 8-Oct & 21 \\
\hline WOMN & MSDW & 14-Oct & 10 \\
\hline MSO & MSDW & 19-Oct & 18 \\
\hline SMDK & RS & 6-Oct & 13 \\
\hline JNIC & DLJ & 26-Oct & 19 \\
\hline CYSV & TWP & 14-Oct & 17 \\
\hline SIMG & CSFB & 5-Oct & 12 \\
\hline IWOV & CSFB & 7-Oct & 17 \\
\hline NAVI & RS & 22-Oct & 14 \\
\hline BWAY & MSDW & $5-$ Oct & 14 \\
\hline ITRU & CSFB & 26-Oct & 18 \\
\hline AETH & $M L$ & 20-Oct & 16 \\
\hline CLIC & GS/ML & 6-Oct & 14 \\
\hline CRDS & COWEN & 19-Oct & 18 \\
\hline SCMR & MSDW & 21-Oct & 38 \\
\hline
\end{tabular}

\begin{tabular}{|c|c|c|}
\hline 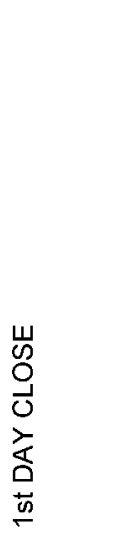 & 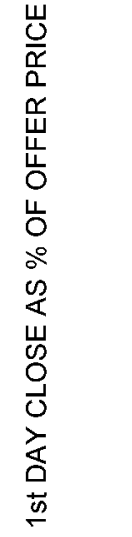 & \begin{tabular}{l}
0 \\
\hdashline
\end{tabular} \\
\hline 9.75 & $88.64 \%$ & $-11.36 \%$ \\
\hline 7.38 & $92.25 \%$ & $-7.75 \%$ \\
\hline 31.5 & $98.44 \%$ & $-1.56 \%$ \\
\hline 9 & $100.00 \%$ & $0.00 \%$ \\
\hline 15 & $100.00 \%$ & $0.00 \%$ \\
\hline 12.56 & $104.67 \%$ & $4.67 \%$ \\
\hline 11.88 & $108.00 \%$ & $8.00 \%$ \\
\hline 8.53 & $113.73 \%$ & $13.73 \%$ \\
\hline 14.06 & $117.17 \%$ & $17.17 \%$ \\
\hline 28.06 & $122.00 \%$ & $22.00 \%$ \\
\hline 11.13 & $123.67 \%$ & $23.67 \%$ \\
\hline 22.38 & $131.65 \%$ & $31.65 \%$ \\
\hline 23.5 & $138.24 \%$ & $38.24 \%$ \\
\hline 25.25 & $148.53 \%$ & $48.53 \%$ \\
\hline 28.5 & $150.00 \%$ & $50.00 \%$ \\
\hline 15.13 & $151.30 \%$ & $51.30 \%$ \\
\hline 27.44 & $171.50 \%$ & $71.50 \%$ \\
\hline 26 & $162.50 \%$ & $62.50 \%$ \\
\hline 16.63 & $166.30 \%$ & $66.30 \%$ \\
\hline 35.5 & $169.05 \%$ & $69.05 \%$ \\
\hline 18.5 & $185.00 \%$ & $85.00 \%$ \\
\hline 35.56 & $197.56 \%$ & $97.56 \%$ \\
\hline 25.81 & $198.54 \%$ & $98.54 \%$ \\
\hline 42 & $221.05 \%$ & $121.05 \%$ \\
\hline 37.75 & $222.06 \%$ & $122.06 \%$ \\
\hline 26.75 & $222.92 \%$ & $122.92 \%$ \\
\hline 41 & $241.18 \%$ & $141.18 \%$ \\
\hline 34.63 & $247.36 \%$ & $147.36 \%$ \\
\hline 42.25 & $301.79 \%$ & $201.79 \%$ \\
\hline 54.38 & $302.11 \%$ & $202.11 \%$ \\
\hline 50 & $312.50 \%$ & $212.50 \%$ \\
\hline 56 & $400.00 \%$ & $300.00 \%$ \\
\hline 78.72 & $437.33 \%$ & $337.33 \%$ \\
\hline 184.75 & $486.18 \%$ & $386.18 \%$ \\
\hline
\end{tabular}

AVERAGES $\quad 92.15 \%$ 
$4.55 \quad 20.36$

$4 \quad 11.2$

$7.25 \quad 50.02$

$4.2 \quad 19.66$

$3.25 \quad 10.42$

$6 \quad 31.79$

$2.9 \quad 20.14$

$7.2 \quad 57.33$

$5 \quad 19.33$

$29.6 \quad 458.48$

$4 \quad 15.86$

$7 \quad 38.14$

$4.6 \quad 15.6$

$10 \quad 66.67$

$3.9 \quad 29.27$

$6.67 \quad 17.64$

$6.84 \quad 20.9$

$6 \quad 50.83$

$3.25 \quad 12.82$

$3.13 \quad 14.33$

3.75

7.2

$4.9 \quad 21.78$

$3.35 \quad 11.13$

$3.9 \quad 25.14$

$3.15 \quad 21.79$

$5.5 \quad 27.19$

$3 \quad 16.87$

$6.5 \quad 37.75$

$6 \quad 26.07$

$4 \quad 32.96$

$3.75 \quad 25.63$

$7.48 \quad 78.03$
0.2235

0.3571

0.1449

0.2136

0.3119

0.1887

0.144

0.1256

0.2587

0.0646

0.2522

0.1835

0.2949

0.15

0.1332

0.3781

0.3273

0.118

0.2535

0.2184

0.0839

0.1484

0.1933

0.225

0.301

0.1551

0.1446

0.2023

0.1778

0.1722

0.2301

0.1214

0.1463

0.0959
웅

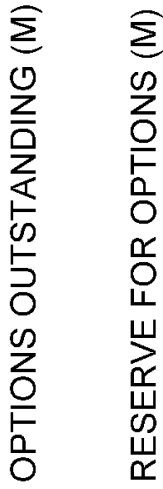

0.682

0.6

1.088

0.63

0.488

0.9

0.435

1.026

0.75

4.44

0.6

1.05

0.69

1.5

0.585

1
1.026

0.9

0.488

0.35

0.563

1.08

0.45

0.735

0.503

0.585

0.472

0.825

0.45

0.975

0.9

0.6

0.563

1.121
1.737

0.846

\section{0}

2.996

0.35

5.432

3.79

5.725

1.475

9.092

3.427

1.495

4.583

5.399

2.59

2.994

2.867

3.266

1.769

2.719

6.869

3.806

7.6

0.905

0.133

$5.067 \quad 1.817$

6.24

2.063

1.056

2.501

7.157

7.722

4.902

5.458

1.5531 .016 $1.686 \quad 18.64$

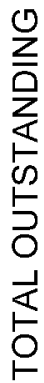

23.85

14.27

61.31

27.29

14.76

40.44

25.12

70.72

23.17

508.01

27.19

43.26

20.87

73.57

36.25

29.37

24.79

55.55

15.08

17.4

55.92

57.19

17.01

29.4

17.87

27.79

27.3

30.52

24.77

46.45

31.87

39.02

28.7

99.48

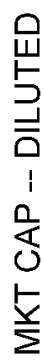

232.49

105.28

1931.2

245.57

221.37

507.93

298.37

603.27

325.77

14254.82

302.59

968.18

490.52

1857.62

1033.21

444.38

680.32

1444.38

250.73

617.66

1034.48

2033.68

438.98

1234.76

674.71

743.33

1119.38

1056.77

1046.66

2525.79

1593.6

2185.01

2264.14

18378.19

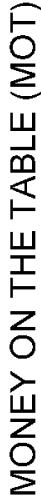

$-6.54$

$-2.85$

$-4.17$

0

3.86

2.93

8.47

11.85

172.24

9.8

43.31

34.39

94.88

42.61

39.35

89.99

69

24.78

50.46

36.66

145.4

44.19

129.61

79.95

66.15

86.93

130.48

97.46

271.94

234.6 193.2

261.89

1262.2

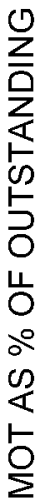

$-0.0281$

$-0.0271$

$-0.0022$

0

0.0076

0.0098

0.014

0.0364

0.0121

0.0324

0.0447

0.0701

0.0511

0.0412

0.0885

0.1323

0.0478

0.0988

0.0817

0.0354

0.0715

0.1007

0.105

0.1185

0.089

0.0777

0.1235

0.0931

0.1077

0.1472

0.0884

0.1157

0.0687

$19.82 \%$

$6.04 \%$ 